\title{
An Investigation of College English Teachers Mediation in Classroom: From Perspective of Teachers and Students
}

\author{
ZHU Yushuang \\ College of Foreign Languages, Jianghan University \\ Wuhan, China \\ E-mail: shirley_tony@163.com
}

Keywords: classroom teaching teacher's mediation the Chinese and foreign English teachers.

\begin{abstract}
Based on Feuerstein's Theory of Mediation, this paper, by means of questionnaire and interview, investigates the Chinese English teachers' views of the importance of each aspect of mediation and their assessment of how often they think they carry out each of these functions in their actual classroom teaching, and students expectation of teachers mediation in classroom. According to the problems reflected from the data, the authors provide some suggestions, hoping to improve the English teaching and teacher education in China.
\end{abstract}

\section{Introduction}

Over the last few decades, many famous theorists conducted the study on foreign language learning motivation. [1] The real increase of students' higher English proficiency, not only need to stimulate their motivation to learn, but also require implementing English pedagogical reform by Graded Education. According to the Vygotsky (1962), the psychologists of social interactionism, the secret of students' effective learning lies in the nature of the social interaction between teacher and student. [2] So for a teacher, an awareness of the degree of match and mismatch between his/her 'espoused' theories and their 'theories-in-action', and the degree of match and mismatch between his/her beliefs and their students understanding about learning as well as the many different ways in which their words and actions can influence the learning that occurs in their classroom, are needed to be understood. [3] As mentors of students, teachers should adjust themselves to be effective mediators.

Based on Feuerstein's Mediation theory, through questionnaire and interview, this paper investigates 45 teachers' perception and practice of mediation in EFL classroom, and 131 students perception of teachers' mediation in class. [4] Implications for EFL teaching and learning are given at the end of the paper.

\section{Research Design}

Research questions

The current study tries to deal with the following research questions:

(1) What are teachers' perceptions on teacher mediation and how do they perform in actual EFL teaching? Is there any gap between their perceptions and practices?

(2)What are students' perceptions on their teachers' mediation? Is there any difference between teachers' perceptions and students'?

\section{Subjects}

Seventy teachers and two hundred and sixty students from the foreign languages school of two universities of Hubei provinces are involved in the questionnaires. Among the 70 teachers, $18(25.7 \%)$ of them are males and $52(74.3 \%)$ of them are females. Among the 260 students, $64(24.6 \%)$ of them are males and 196(75.4) of them are females. They are from three grades, grade 1 (27.7\%), grade 2(45.5\%) and grade 3(26.9\%), all of them major in either English education or 
Business English.

\section{Data collection and analysis}

The questionnaires for both teachers and students are adopted from William and Burden (2000). Teachers' questionnaires consist of two sections. In section one, teachers are asked to give their viewpoint on mediation with a scale of 'not at all', 'not very', 'somewhat', 'quite important' to 'very important'. In section two, teachers were required to evaluate their actual performance of teacher mediation in their teaching with a five-point scale ranging from 'very often' to 'never'. The questionnaires administered to 76 teachers were all conducted in earnest attempt and retrieved well, 70 (about 92.1\%) of the questionnaires are effective. The scale showed adequate internal consistency, the Cronbach's Alpha $(\alpha)$ was .793 in the current study.

After the accomplishment of the questionnaires, 5 teachers and 20 students were randomly chosen and were interviewed for a further understanding of teacher mediation in EFL classroom. The interviews were carried out in a comfortable and relaxing manner in Chinese.

All the quantitative data were put into the SPSS 18.0; descriptive statistics of teachers' perception and practice of teacher mediation were analyzed. Paired Sample T-test was carried out to exam the difference between teachers' perception and practice of teacher mediation in the two perspectives, and an Independent sample T-test for the difference between teachers and students' perception of teacher mediation. The data from interview were recorded and then transcribed.

\section{Results and discussions}

\section{Teachers' perceptions and practices on teacher mediation}

The results of the paired-sample T-test of teachers' perceptions and actions based on the 12 variables were showed in table1.

TABLE 1 PAIRED SAMPLES STATISTICS

\begin{tabular}{|c|c|c|c|c|c|}
\hline mediation & & Mean & $\begin{array}{c}\text { Std. } \\
\text { Deviation }\end{array}$ & $\mathrm{t}$ & $\begin{array}{c}\text { Sig. } \\
\text { (2-tailed) }\end{array}$ \\
\hline $\begin{array}{l}\text { shared } \\
\text { intention }\end{array}$ & $\begin{array}{l}\text { perception } \\
\text { practice }\end{array}$ & $\begin{array}{l}4.4000 \\
4.3571\end{array}$ & $\begin{array}{l}.90730 \\
.79920\end{array}$ & .435 & .665 \\
\hline $\begin{array}{l}\text { significan } \\
\text { ce }\end{array}$ & $\begin{array}{l}\text { perception } \\
\text { practice }\end{array}$ & $\begin{array}{l}3.3143 \\
3.6857\end{array}$ & $\begin{array}{r}1.09733 \\
.98603\end{array}$ & $\begin{array}{r}-2.95 \\
4\end{array}$ & .004 \\
\hline $\begin{array}{l}\text { transcend } \\
\text { ence }\end{array}$ & $\begin{array}{l}\text { perception } \\
\text { practice }\end{array}$ & $\begin{array}{l}3.2571 \\
3.3286\end{array}$ & $\begin{array}{l}1.16328 \\
1.03169\end{array}$ & -.575 & .567 \\
\hline $\begin{array}{l}\text { sense of } \\
\text { competen } \\
\text { ce }\end{array}$ & $\begin{array}{l}\text { perception } \\
\text { practice }\end{array}$ & $\begin{array}{l}4.5000 \\
3.9714\end{array}$ & $\begin{array}{l}.71728 \\
.88418\end{array}$ & 4.121 & .000 \\
\hline $\begin{array}{l}\text { control of } \\
\text { own } \\
\text { behavior }\end{array}$ & $\begin{array}{l}\text { perception } \\
\text { practice }\end{array}$ & $\begin{array}{l}4.0714 \\
3.5714\end{array}$ & $\begin{array}{l}.68781 \\
.94134\end{array}$ & 4.664 & .000 \\
\hline $\begin{array}{l}\text { goal-setti } \\
\text { ng }\end{array}$ & $\begin{array}{l}\text { perception } \\
\text { practice }\end{array}$ & $\begin{array}{l}3.8857 \\
3.2000\end{array}$ & $\begin{array}{l}.84344 \\
.98687 \\
\end{array}$ & 5.228 & .000 \\
\hline challenge & $\begin{array}{l}\text { perception } \\
\text { practice }\end{array}$ & $\begin{array}{l}3.4000 \\
2.9286\end{array}$ & $\begin{array}{r}1.22060 \\
.92190 \\
\end{array}$ & 4.323 & .000 \\
\hline $\begin{array}{l}\text { awareness } \\
\text { of change }\end{array}$ & $\begin{array}{l}\text { perception } \\
\text { practice }\end{array}$ & $\begin{array}{l}2.8143 \\
2.5143\end{array}$ & $\begin{array}{r}1.01143 \\
.84687 \\
\end{array}$ & 2.165 & .034 \\
\hline $\begin{array}{l}\text { believe in } \\
\text { positive } \\
\text { outcome }\end{array}$ & $\begin{array}{l}\text { perception } \\
\text { practice }\end{array}$ & $\begin{array}{l}3.7429 \\
3.1857\end{array}$ & $\begin{array}{l}.81090 \\
.83913\end{array}$ & 5.516 & .000 \\
\hline sharing & $\begin{array}{l}\text { perception } \\
\text { practice }\end{array}$ & $\begin{array}{l}3.9000 \\
3.3286\end{array}$ & $\begin{array}{l}.93483 \\
.92817\end{array}$ & 4.920 & .000 \\
\hline $\begin{array}{l}\text { individual } \\
\text { ity }\end{array}$ & $\begin{array}{l}\text { perception } \\
\text { practice }\end{array}$ & $\begin{array}{l}3.5286 \\
3.2000\end{array}$ & $\begin{array}{l}1.17611 \\
1.13699\end{array}$ & 1.686 & .096 \\
\hline $\begin{array}{l}\text { sense of } \\
\text { belonging }\end{array}$ & $\begin{array}{l}\text { perception } \\
\text { practice }\end{array}$ & $\begin{array}{l}3.0571 \\
2.6000\end{array}$ & $\begin{array}{l}1.19037 \\
1.13444\end{array}$ & 4.270 & .000 \\
\hline
\end{tabular}

As can be seen from table 1, among the 12 perspectives of teacher mediation, teachers take shared intention, sense of competence, control of own behavior as the most important, the mean of 
the three aspects are higher than 4.0. Awareness of change was considered the least important $(\mathrm{M}=2.8143$, S.D. =1.01143). Lai (2004) and Yang (2006) also found their subjects take shared intention as the most important perspective, and awareness of change as the least. This is possibly because of the traditional way of evaluation; the school usually employs the final and mid-term exam to measure students' achievement in a term. Most of the teachers failed to realize the importance of cultivating students' awareness of change.

From the descriptive statistics of the practices of teachers' mediation in classroom, we can see that the best performed is shared intention, and it is the only one perspective scored above 4.0, while challenge, awareness of change and sense of belonging scored below 3.0 which means those teachers rarely performed those meditational functions in class. The general level of practices on teacher mediation is lower the teachers' perception of teacher mediation.

As for the differences between teachers' perceptions and practices, the significance exists on all the variables except shared intention, transcendence and individuality. The p-values of significance, sense of competence, control of behavior, goal-setting, challenge, believe in positive outcome and sharing show that teachers perception and practice upon these perspectives are significantly different, the P-value are less than .005. The P-value for awareness of change is .034, which indicates a relevantly smaller difference but still a significant one. [5] Here we can add some analysis of the three perspectives in which teachers perform as well as they perceive them.

\section{Teachers' and students' perceptions of teacher mediation}

The results of the Independent Sample T-test of teachers' and students' perceptions on the 12 variables were showed in table 2 . 
TABLE 2 INDEPENDENT SAMPLE T-TEST

\begin{tabular}{|c|c|c|c|c|c|c|}
\hline & \multirow[t]{2}{*}{ subject } & \multirow[b]{2}{*}{ Mean } & \multirow[b]{2}{*}{$\begin{array}{c}\text { Std. } \\
\text { Deviatio } \\
n\end{array}$} & \multicolumn{3}{|c|}{$\begin{array}{l}\text { t-test for Equality of } \\
\text { Means }\end{array}$} \\
\hline & & & & $\begin{array}{c}\text { Mean } \\
\text { differenc } \\
\mathrm{e}\end{array}$ & \begin{tabular}{|c} 
Sig. \\
(2-taile \\
d)
\end{tabular} & $\mathrm{t}$ \\
\hline \multirow[t]{2}{*}{$\begin{array}{l}\text { Shared } \\
\text { intention }\end{array}$} & student & $\begin{array}{r}4.37 \\
14\end{array}$ & .93517 & \multirow[t]{2}{*}{.31374} & \multirow[t]{2}{*}{.016} & \multirow[t]{2}{*}{$\begin{array}{r}2.42 \\
6\end{array}$} \\
\hline & teacher & $\begin{array}{r}4.05 \\
77\end{array}$ & .96689 & & & \\
\hline \multirow[t]{2}{*}{ Significance } & student & $\begin{array}{r}3.31 \\
43\end{array}$ & $\begin{array}{r}1.1234 \\
4\end{array}$ & \multirow[t]{2}{*}{-.16264} & \multirow[t]{2}{*}{.236} & \multirow[t]{2}{*}{$\begin{array}{r}-1.1 \\
86\end{array}$} \\
\hline & teacher & $\begin{array}{r}3.47 \\
69\end{array}$ & .98808 & & & \\
\hline \multirow[t]{2}{*}{$\begin{array}{l}\text { Transcenden } \\
\text { ce }\end{array}$} & student & $\begin{array}{r}3.20 \\
00\end{array}$ & $\begin{array}{r}1.1241 \\
7\end{array}$ & \multirow[t]{2}{*}{-.08077} & \multirow[t]{2}{*}{.577} & \multirow[t]{2}{*}{$\begin{array}{r}-.55 \\
9\end{array}$} \\
\hline & teacher & $\begin{array}{r}3.28 \\
08\end{array}$ & $\begin{array}{r}1.0590 \\
7\end{array}$ & & & \\
\hline \multirow[t]{2}{*}{$\begin{array}{l}\text { Sense of } \\
\text { competence }\end{array}$} & student & $\begin{array}{r}4.51 \\
43\end{array}$ & .73707 & \multirow[t]{2}{*}{.23352} & \multirow[t]{2}{*}{.030} & \multirow[t]{2}{*}{$\begin{array}{r}2.18 \\
8\end{array}$} \\
\hline & teacher & $\begin{array}{r}4.28 \\
08\end{array}$ & .97161 & & & \\
\hline \multirow{2}{*}{$\begin{array}{l}\text { Control } \\
\text { own } \\
\text { behavior }\end{array}$} & student & $\begin{array}{r}4.05 \\
71\end{array}$ & .72002 & \multirow[t]{2}{*}{-.08901} & \multirow[t]{2}{*}{.401} & \multirow[t]{2}{*}{$\begin{array}{r}-.84 \\
2\end{array}$} \\
\hline & teacher & $\begin{array}{r}4.14 \\
62 \\
\end{array}$ & .99117 & & & \\
\hline \multirow[t]{2}{*}{ Goal-setting } & student & $\begin{array}{r}3.88 \\
57\end{array}$ & .82608 & \multirow[t]{4}{*}{.31648} & \multirow[t]{4}{*}{.010} & \multirow[t]{4}{*}{$\begin{array}{r}2.61 \\
0\end{array}$} \\
\hline & teacher & $\begin{array}{r}3.56 \\
92\end{array}$ & $\begin{array}{r}1.1351 \\
8\end{array}$ & & & \\
\hline \multirow[t]{2}{*}{ Challenge } & student & $\begin{array}{r}3.45 \\
71\end{array}$ & $\begin{array}{r}1.0589 \\
3\end{array}$ & & & \\
\hline & teacher & $\begin{array}{r}3.53 \\
46\end{array}$ & $\begin{array}{r}1.1299 \\
5\end{array}$ & & & \\
\hline \multirow[t]{2}{*}{$\begin{array}{l}\text { Awareness of } \\
\text { change }\end{array}$} & student & $\begin{array}{r}2.85 \\
71\end{array}$ & .83901 & \multirow[t]{2}{*}{.04560} & \multirow[t]{2}{*}{.708} & \multirow[t]{2}{*}{.376} \\
\hline & teacher & $\begin{array}{r}2.81 \\
15\end{array}$ & $\begin{array}{r}1.1041 \\
6\end{array}$ & & & \\
\hline $\begin{array}{l}\text { Belief in } \\
\text { positive } \\
\text { outcome }\end{array}$ & $\begin{array}{l}\text { student } \\
\text { teacher }\end{array}$ & $\begin{array}{r}3.74 \\
29 \\
\\
3.41 \\
54\end{array}$ & $\begin{array}{r}.84589 \\
1.1676 \\
8\end{array}$ & .32747 & .009 & $\begin{array}{r}2.63 \\
3\end{array}$ \\
\hline Sharing & teacher & $\begin{array}{r}3.82 \\
86 \\
3.47 \\
69\end{array}$ & $\begin{array}{r}1.0884 \\
8\end{array}$ & .35165 & .007 & $\begin{array}{r}2.73 \\
3\end{array}$ \\
\hline Individuality & student & $\begin{array}{r}3.32 \\
31 \\
\end{array}$ & $\begin{array}{r}1.0198 \\
9 \\
1.1869 \\
0\end{array}$ & .33407 & .021 & $\begin{array}{r}2.34 \\
6\end{array}$ \\
\hline$\left|\begin{array}{ll}\text { Sense } & \text { of } \\
\text { belonging } & \end{array}\right|$ & teache & $\begin{array}{r}3.0 \\
769\end{array}$ & $\begin{array}{r}1.094 \\
85\end{array}$ & .09451 & .522 & .642 \\
\hline
\end{tabular}

From table 2, we can see that teachers and students agree upon the three most important teacher mediation functions, which are shared intention, sense of competence and control of behavior. The average mean for both teachers and students are above 4.0. Awareness of change (Mteacher=2.8115, Mstudent=2.8571) and sense of belonging (Mteacher=3.0769, Mstudent=3.1714) were perceived as the least important mediation function by teachers and students as well. 
The significant difference of perception on teacher mediation between teachers and students shows on shared intention $(\mathrm{p}=.016, \mathrm{t}=2.426)$, sense of competence $(\mathrm{p}=.30, \mathrm{t}=2.188)$, goal-setting $(\mathrm{p}=.010, \mathrm{t}=2.610)$, belief in positive outcome $(\mathrm{p}=.009, \mathrm{t}=2.633)$, sharing $(\mathrm{p}=.007, \mathrm{t}=2.733)$, individuality $(\mathrm{p}=.021, \mathrm{t}=2.346)$, students' expectations of teachers' mediation function are significantly higher than teachers own perception of their mediation functions in classroom, which means students expect their teachers to do more about shared intention, cultivating sense of competence, goal-setting, belief in positive outcome, sharing and individuality. In a certain sense, this might not be a good phenomenon, since it is the final goal of education in college English class to cultivate autonomous learners. [6] It might not be appropriate for them to expect too much on teachers, although as teachers, they should try their best to fulfill their function of mediation in classroom

\section{Conclusion}

Though the sample in this study is limited, but the results of the investigation do bring us to think about problems on teacher mediation in ESL classroom in China. First, Generally speaking teachers are aware of the importance of teacher mediation in EFL classroom except helping students raising the awareness of change. However there are big discrepancies between what teachers believe and how they behave about their mediate function in class except shared intention, transcendence and individuality. [7] Second, Students expect more from their teachers about teacher mediation esp. in perspective of shared intention, sense of competence, goal-setting, belief in positive outcome, sharing, and individuality. Third, teachers and students are similar upon the ranking of teacher mediation. Awareness of change and sense of belonging have been labeled as least important teacher mediation by students and teachers. Shared intention, sense of competence and control of behavior were perceived as the three most important teacher mediations by teachers and students.

\section{Reference}

[1] Lambert. Culture and Language as Factors in Learning and Education [M]. Bellinghan, Washington: Fifth Western Washington Symposium on Learning,

[2] 1955.Ellis, G and B. Sinclair .Learning to Learn English: A Course in Learner Training.Teacher Handbook. Cambridge: Cambridge University Press, 1989.

[3] Faircloth B S \& Hamm J V. Sense of belonging among high school students representing 4 ethnic groups [J]. Journal of Youth and Adolescence, 2005, 34 (4): 293-309.

[4] Feuerstein , R. , Y. Rand , M. Hof fman \& R. Miller .1980. Instrumental Enrichment [ M ] . Glenview ,Illinois : Scot t Foresman.

[5] Kumaravadivelu, B. 2006.Understanding Language Teaching: From Method to Postmethod. Mahwah, New Jersey: Lawrence Erlbaum Associates, Publishers.

[6] Osterman K F. Students' need for belonging in the school community [J]. Review of Educational Research, 2000, 70 (3 ): 323-362.

[7] Oxford, R. \& Shearin, J. Language Learning Motivation: Expanding the Theoretical Framework [J]. Modern Language Journal, 1994. 